\title{
Disembodied Voice and Embodied Affect: e-Reading in Early Childhood Education
}

\author{
Carina Hermansson* \\ Umeå University, Sweden
}

\begin{abstract}
This article is based on observations made in a Swedish digital early childhood classroom during reading time. The question of 'what is happening' in the digital classroom when six-year-olds read a fictional electronic book is explored through video observations focusing on children learning to read by engaging in e-books. Informed by affect, as described by Baruch de Spinoza and interpreted by Gilles Deleuze, this article provides a way to attend to the highly dynamic encounters between bodies, ideas and materiality that characterize the children's engagement in e-reading. The analysis suggests that the digital voice is a vital component for activating engagement in and a drive for reading through the moments and movements of embodied reading when children co-read a fictional e-book on their own. Focusing on how e-book reading is enacted in the educational everyday reading practices, this article is an empirically grounded contribution to the understanding of how e-reading is constituted in contemporary digital classroom in all its complexity.
\end{abstract}

Keywords: E-books; embodiment; affect; reading; early childhood education

Received: January 2016; Accepted: May 2016; Published: March 2017

\section{Introduction}

The sofa outside the classroom turns into a reading den when Oskar and Carolin, aged 6, read the e-book "Erik at the Circus". Embedded in pillows they huddle up against each other engaged in the act of reading. The voice in the e-book reads: "Erik wants to ride a little pony but they have to wait because there was a long line". At the same time as Carolin pauses the recording, she draws a long line in the air with her arm saying, "It's a looong, loooong, long line". And so they keep on reading; repeating in chorus what the voice reads while rhythmically moving their hands in the air.

(Field notes, the Woodland school, 26 May, 2015)

Reading literature is a given activity in the daily literacy training in early childhood education, and so also in the digital classroom where the field observation above

^Corresponding author: Carina Hermansson, Department of Language Studies, Umeå University, SE-901 87 Umeå, Sweden, Email: carina.hermansson@umu.se

(C)2017 C. Hermansson. This is an Open Access article distributed under the terms of the Creative Commons Attribution 4.0 International License (http://creativecommons.org/licenses/by/4.0/), allowing third parties to copy and redistribute the material in any medium or format and to remix, transform, and build upon the material for any purpose, even commercially, provided the original work is properly cited and states its license.

Citation: C. Hermansson. "Disembodied Voice and Embodied Affect: e-Reading in Early Childhood Education." Nordic fournal of Literacy Research, Vol. 3, 2017, pp. 12-25. http://dx.doi.org/10.23865/njlr.v3.467 
was made. Although this field note entry captures an ordinary and seemingly mundane activity of reading an electronic book (e-book), ${ }^{1}$ an analytical reading of it can reveal a multitude of unpredictable, energetic and dynamic moments and movements transforming the activity, such as the children's embodied repeated reading described above - mo(ve)ments that are not directly expressed and often pass unnoticed by the teachers in the observed classrooms. Guided by the initial purpose to seek ways to understand young children's engagement in digital reading, this study deals with research highlighting what is happening in the digital classroom (e.g. Mangen \& Kuiken, 2014; Roskos et al., 2014). By taking a closer look at children's engagement with e-books, and specifically mo(ve)ments of intensity, the article describes and discusses the moments and movements that shared e-reading of a fictional e-book may give rise to and how these mo(ve)ments are constituted and experienced in the everyday classroom of six- and seven-year-olds.

To explore these daily mo(ve)ments of e-reading I center on (1) the elements (e.g. talk, bodily movement, the digital voice, or the touch screen) that are more or less forceful in the e-reading activity and (2) when, how and together with what these elements become more forceful, or are forceless, thus creating intensity. I adopt a complex-sensitive approach to recognize the activities of e-reading with respect to intensities, connectivity and the flow of change. Specifically, I use an affective methodology (see Coleman \& Ringrose, 2013; Knudsen \& Stage, 2015) to develop the analysis. The concept of affect, as developed by Baruch Spinoza and interpreted by Gilles Deleuze (1988), serves to draw attention to what moves us, that is, to relations in which the children either expand or restrict their capacity to act. The article is a contribution to an understanding of how mo(ve)ments of e-reading are constituted and experienced through interaction between bodies, ideas and materiality, empirically grounded in a contemporary Swedish educational context. In attending to an affective methodology, this article provides research methodological and pedagogical tools to consider the situatedness of the children's acts of reading and the processes of learningto-read that they generate.

\section{E-book activities in early childhood education}

Although early forms of electronic books have been available to children on computers for many years, they have recently been given more attention in education because of the rapid technological improvements and greater affordability of mobile devices. Thus e-books are a fairly new, but a rapidly growing interest in the research field of early childhood literacy education.

When presented in research, activities that employ e-books are most often compared and contrasted with more traditional printlike reading activities. These

\footnotetext{
${ }^{1}$ An electronic book (also known as a digital book) is a digital representation of a printed novel or book, that is, an electronic file that can be read on a computer, phone, digital tablet, e-book reader, or a device that supports the book's file type. In this study it is further defined to have, as a minimum, oral narration in addition to written text, and some form of multimedia (e.g. visual effects and sound effects).
} 


\section{Hermansson}

studies depict a wide variation in the effects that e-books have as a curricular resource and how students interact with and respond to digital reading tools and e-book texts. Several studies exploring the impact of digital reading tools on children's emergent literacies claim that the use of multimedia features such as hotspots, game-like activities or scrawling in the book leads to shallow reading and short attention spans (e.g. Takacs, Swart \& Bus, 2015). It is suggested that such features necessitate skills and abilities like task switching, which involve an excessive cognitive load that may have negative consequences for story comprehension (e.g. Bus, Takacs, \& Kegel, 2014). At the same time, multimedia additions such as visual illustrations or other non-verbal information that work in harmony with the narration have been shown to improve children's story comprehension (e.g. Lysenko \& Abrami, 2014; Smeets \& Bus, 2012). Verhallen and Bus (2011) have, for example, demonstrated that children can learn to use visual and audio cues for comprehension when animated pictures or sound effects match the simultaneously presented story text. Multimedia features may also offer particular benefits to children in groups less likely to be reading at the expected level for their age. Students with learning disabilities significantly improved reading speed and comprehension when reading on screen (e.g. Gonzalez, 2014; Schneps, et al., 2013). Accordingly, multimedia features of e-books support culturally and linguistically diverse students' understanding of the text (Brown, 2016).

Furthermore, with respect to e-book activities in early childhood education there is an established interest in studying the impact that e-books have on motivation and engagement. Scholars indicate an agreement that e-books increase students' engagement and motivation to read, in particular, struggling readers (e.g. Ciampa, 2012). Research has also highlighted and discussed the increased preference among children to read on screen rather than on paper and its association to a generally positive impact especially on boys' motivation for print reading (e.g. Rasmusson, 2014; Swedish National Agency for Education, 2012).

However, the ways in which e-book activities "work", that is, what they offer to the classroom have not been fully explored. Specifically, Mangen (2016) points out that there is a need for "a more nuanced understanding of how the embodied and multisensory reader interacts with various ergonomic as well as audiovisual affordances of technological substrates" (p. 247). Also, Burnett (2009) together with Luke, Woods and Dooley (2011) claim a need for additional research addressing the concerns manifested in specific classrooms from an interrelation perspective in which social relations, discourses and power are acknowledged. The present study responds to these calls for more research by describing and discussing how processes of e-reading are constituted and experienced in relation to bodies, ideas and materiality when sixyear-olds read a fictional e-book.

In foregrounding the affective capacity of the e-reading activity, this article is aligned with scholars addressing a pronounced gap in educational research on affect and literacy (e.g. Cole, 2009; Dufresne, 2006; Olsson, 2013). In the tradition of Spinoza and Deleuze, they explored the possibilities of what bodies can do in the classroom setting. Informed by Albrecht-Crane and Daryl Slack's argument that 
"[t]he importance of affect in the classroom is inadequately considered in scholarship on pedagogy" (2003, p. 191), this study provides an exploration of the immediate, the indeterminate and the everyday processes of e-book-reading in schools.

\section{Methodology}

To understand how the students' interest in reading, as described in the introductory field memo, emerges and operates, I apply the notion of affect as described in Deleuze's reading of Spinoza. When analyzing the ways in which students' processes of e-reading are constituted in the everyday classroom of six- and seven-year-olds, specific attention is paid to the affective capacity, that is, how affect may extend or stabilize the ways that processes of e-reading "become".

\section{Affective methodology}

Intrigued by the principle of becoming, Deleuze (1988) turned to the concept of affect to describe how a practice may enhance or diminish a body's capacity or power to act. He explains affect as an action or force that operates at the moment of contact body to body (human and non-human bodies); a force that drives transformative movements of becoming through the power "to affect and be affected" (Deleuze \& Guattari, 1987, p. 261). This force is understood as beyond or before thought, emotion or interpretation - as pre-personal. Turning to Deleuze (1988) and Deleuze and Guattari's (1987) interpretation of Spinoza, Hickey-Moody and Malins (2007, p. 9) explain the difference in nature between affect and emotions.

Affect is that which is felt before it is thought; it has visceral impact on the body before it gives subjective or emotive meaning. [...] Affect is ... very different from emotion: it is an asubjective bodily response to an encounter. Emotion comes later, a classifying or stratifying of affect.

In this sense, affect shapes a body's capacity to act or respond to a situation in which this productive force of affect is registered as feelings, emotions, atmosphere or senses. As transcribed in the introductory memo, something changes in the children's talk and glances and the printed words on the screen when the disembodied voice of the e-book resonates with the children's earlier experiences of, possibly, cozy places of reading at home. The affective dynamics operating in these contacts inscribes and transforms the assemblage of e-reading into a process of embodied repeated reading through which the feeling of joy and embodied intensity may travel.

Applying a methodology inspired by Deleuze's thinking about affect (cf. Coleman \& Ringrose, 2013; Knudsen \& Stage, 2015; Seyfert, 2012) entails exploring what is happening in the classroom and what makes people do/not do things. In highlighting the active outcome of the social-material encounters happening between the young readers, the e-book and the text, this article explores how these encounters produce processes of e-reading that may, or may not, prompt a drive for reading. Accordingly, e-reading activities are, through the lens of the affective methodology, seen as being 


\section{Hermansson}

continually modified by the myriad of encounters taking place between bodies involved, bodies such as the digital tablet, the sofa, the students' bodily movements and other entities.

Affective methodology provides a language or vocabulary to describe students' needs as e-readers and to analyze the ways in which e-reading processes unfold and develop, increase or decrease, in their capacity to produce moments and movements of intensity and sense through, for example, bodily movements, joy and passivity. Thus, this article does not set out to generalize about children's engagement with e-books in education, but rather to focus on lived moments of a particular specificity.

\section{Empirical settings}

Data for this study were drawn from a larger video-ethnographic classroom study examining six-year-olds' e-book activities. Although school starts at the age of seven in Sweden, most six-year-olds attend non-mandatory preschool classes (Statistics Sweden, 2014), instituted by the Swedish government in 1998. A main characteristic of the preschool class is the idea of educare, in which childcare and education are enacted in a balanced mix (Swedish National Agency for Education, 2001) under the provision of the Swedish public school curriculum (Swedish National Agency for Education, 2011).

Three preschool classes at two different schools in the south of Sweden were involved. Two preschool classes comprising 27 children and two teachers, at an inner city primary school, the Seaside, took part in the study from September 2013 until May 2014. Thirteen children and one teacher from a primary school, the Woodland, in a rural village took part from January until May 2015. The three classes were diverse in terms of social and cultural background, and were equally divided in terms of gender. Each child and teacher had access to his/her own tablet computer. Different e-book activities across the curriculum were video recorded during one school day every other week. In taking part as a participant observer, the prolonged fieldwork allowed time to become socialized into the literacy activities, to build trust with the participants and to observe the digital reading activities repeatedly. The continued fieldwork together with the systematic process of analysis suggested the degree of typicality of a phenomenon and the range of variation within the data. For the purposes of this article, I draw on data from the Woodland observations to focus on the continuous production of e-reading processes in a classroom.

\section{Analysis}

The affective methodology used here (see Coleman \& Ringrose, 2013; Knudsen \& Stage, 2015), builds on tracing and mapping the network of forces, intensities, capacities and relationalities (see Alvermann, 2000; Hagood, 2004) in which the e-reading processes are created. Mapping these aspects involves following connections between, for example, bodily movements, speech, the disembodied reading voice, the digital tablet and knowledge about learning to read, i.e. between things, human and nonhuman elements. 
The analytical process involved three interconnected, performative layers of mapping and analyzing. The first analytical layer of mapping data provided an overview related to the content of e-reading, social processes and context. A second layer involved additional analysis in which the map-making embodied the principles of the methodological approach and the research focus. Thus, I produced a map that involved a series of interconnected examples that "seemed to be engaged or interjected in such a way as to make new relations possible" (Leander \& Rowe, 2006, p. 440). The analysis of mapping data in the first and second layer involved the production of transcripts in which time, the digtal read aloud voice, actions, speech, material and the alphabetic texts were sequentially and temporally organized (cf. Goodwin, 2000) via the qualitative computer-based analysis tool Transana. $^{2}$ In thinking with affect, the example, Erik at the Circus, was "selected and assessed according to their power to act and intervene" (Colebrook, 2002, p. xliv) and a narrative description was produced throughout the third layer of the analytical process.

Ethical issues have been considered and approved by the university's ethical board and the central principles of informed consent and confidentiality were ensured throughout the research process. All names of participants are fictional.

\section{The e-reading activity, "Erik at the Circus"}

The selected example, "Erik at the Circus", consists of an interaction between children, the story content of a digital literary text, the teacher and the same type of electronic software and device used in other analyzed e-book activities. The example demonstrates commonly occurring processes of e-reading as observed in the digital classrooms. Before analyzing four excerpts from the transcript in more detail, a short introduction to the e-book activity "Erik at the Circus" is presented.

The e-book-reading was part of an instructional unit that the teacher had planned. With the narrative e-book, Erik at the Circus (Bengtsson, 2011), the reader could choose between displaying the pictorial or the alphabetic text, listening to the readaloud voice of the text or creating access to both the text and the read-aloud voice at the same time. It had no additional customization tools, such as a notetaking feature, built-in dictionary or Internet links, but it had features to adjust the font size, the speed of the read-aloud voice and the number of sentences displayed, as well as the length of highlighted text. Initially, the teacher, Marie, listened to the first few pages of the narrative with the whole class before letting the students continue to read in pairs on their individual tablets. The focal digital reading activity was performed by two six-year-old readers, Oskar and Carolin, in the hallway.

Carrying their digital tablet, Oskar and Carolin arrange themselves on the sofa. The following excerpt illustrates how processes of e-reading happen in the classroom as materials, social dimensions, experiences and emotions come together.

\footnotetext{
${ }^{2}$ Transana 2.60. Available online at: http://www.transana.org Accessed May 2014.
} 


\section{Hermansson}

The e-book, classmates and space - bodies in (e)motion

Oskar moves the yellow sofa cushion to come closer to Carolin. They half-lie, half-sit in the corner of the grey sofa. They are so close to each other that both of them can touch and see what is on the digital screen that lies in Carolin's lap. They try to log in to their digital library but fail, and when Marie comes to help them, Carolin stresses that "we are lying ((on the sofa)) because it seems so cozy [vi ligger för det verkar så mysigt]". Marie fixes their login and within a few seconds Carolin and Oskar have started the digital narrator's voice, which says, "Erik at the Circus [Erik på cirkus]". At the same moment that Carolin touches the pause button of the digital voice she remarks that there is a clown on the title page and Oskar declares, "It says Erik [Det står Erik]". While leaning across Carolin's chest, he traces the letters on the screen with his finger reading "Erik" letter-by-letter, "E-R-I-K".

This prelude turns into a cozy scene of reading in which space, experiences and materiality seem to be as important as the collaboration between Carolin and Oskar. Together, Carolin and Oskar explore how to log in to the e-book. They also co-create the reading space, a collaboration which involves an intense negotiation about issues such as which button to push and which letters and numbers to write to log in. Additionally, the production of a reading space on the sofa indicates knowledge of reading as an activity involving sitting in a comfortable, cozy place - an activity often associated with out-ofschool reading. Just as the social and cultural relationship established in their exploration of the e-book shapes the reading activity, the sofa, the cushions and the digital tablet organize the activity. It is a complex scene of contingent interplay. The soft surface of the sofa in contact with their bodies and gravitational force make Carolin and Oskar slide towards each other, creating a space in which their arms, hands and fingers may land on the even surface of the digital tablet, where a finger can smoothly move along the letters displayed on the screen. The power, or affect, as Deleuze (1988) terms it, operating in this particular encounter, extends Oskar and Carolin's capacity to act and is registered as an enjoyable engagement in creating a reading space on the sofa.

These entanglements or encounters work in a precise sense to compose various moments or movements of reading, not only in socially and culturally constructed ways, but also material ways. The cozy feeling of reading is constituted in a web of encounters between the sound waves of the disembodied reading voice travelling through the air, connecting with the outer ear in which the vibrations convert into nervous impulses connecting to the brain and to knowledge about letters (soundsymbol correlation) and to muscles in the hand forming and moving the finger along the letters on the screen. The voice, the digital tablet and the sofa cushions become more than tools that Carolin and Oskar use and access. In actual fact, Carolin, Oskar and the voice work in sync as one body, or rather, as different parts of one body, physically distinct but still intrinsically entangled in mutual engagements.

The described activity unfolds not only a movement of building a cozy place for reading, but also a training of sound-symbol correlation. The voice reading the title of the book is followed by Oskar repeating the title in full while pointing to each letter and then simply read "Erik" letter-by-letter. The voice captures the children's attention, 
creating a turning point or a change, in which a movement of identifying letters and reading begins. At this very moment, the change is registered as an intense experience offering possibility for training sound-symbol correlation, including phonological rehearsal, iconic memory and associative memory. As such, this example illustrates how encounters between, for example, the read aloud voice, the digital tablet and the sofa create opportunities to transform, act, and shape the activity of e-reading. As is shown below, assemblages involving the digital read aloud voice become essential to how the e-reading activity emerges, transforms and changes.

\section{The disembodied voice and mo(ve)ments of embodied reading}

While the digital reading voice introduces Erik, the main character, and his father going to the circus, Carolin scrolls the text down to the next animation. It is a blackand-white picture of Erik and his father. The voice continues: "They see a large tent. It is red and yellow [De ser ett stort tält. Det är rött och gult]". Suddenly, as the voice reads, "There are many people there [Där är fullt med folk]", Carolin pauses the sound recording and throws her arms open wide.

Then the voice announces that a clown has entered the ring. He has a red nose and big shoes. While the voice is still talking, Carolin repeats, in a funny bass voice, "red nose and big shoes [röd näsa och stora skor]", pointing to her nose and using her hands to show the size of big shoes. The voice continues to tell them that the clown is going to play the violin, although he does not know how, to which Carolin responds.

Carolin (C): He doesn't know how to play the violin. But he wants to. No, wait. He will play the violin, but doesn't know how to, but he loves it. [Han kan inte spela fiol. Men han vill. Nej, vänta. Han ska spela fiol, men han kan inte, men han tycker det är jätteroligt.] ((Carolin starts the sound recording))

Sound recording (SR): Erik laughs so much that his stomach hurts. [Erik skrattar så han får ont i magen]

C: ((Carolin orients towards Oskar)) Just think. Imagine if we start laughing so much that our stomachs hurt. [Tänk. Tänk om vi börjar skratta så vi får ont i magen.] ((Oskar pulls up his legs, laughs, mimics gestures, twists and turns on the sofa. Carolin starts the sound recording))

Right from the start of this example, the recorded voice is part of an intensity working in unpredictable ways in relation to the teacher's initial instruction that they should talk about what they think of while reading the text. As part of a dominant cognitive and metacognitive educational discourse of reading, the instruction aims to develop reading skills such as awareness and comprehension (cf. Westlund, 2015). Accordingly, the example shows moments of creating meaning out of shared information, for instance, when Oskar and Carolin together and orally sound out and decipher words and parts of sentences like "red nose and big shoes". It is interesting how this process of identifying and making sense of shared information is also materialized in embodied intensity in a way that has no relation to the teacher's instruction or to experiences of the collective introduction to the e-reading activity. Instead of encouraging embodied actions to make sense of the reading, the teacher suggested cognitive associations. 


\section{Hermansson}

This example illustrates how embodied actions are strongly linked to moments in which the voice and the experiences of Oskar and Carolin are intrinsically intertwined, evoking the potential for engagement in producing and communicating sense through embodied actions in unpredictable ways. Yet another moment of embodied intensity occurs when the voice reads, "There are many people". Unexpectedly, Carolin throws her arms open wide. The phrase" [t] here are many people" might evoke the thought of a large crowd of people, or an experience of standing at the top of the circus tent getting an overall look at the crowd and the performance, or .... What happens next is an actualization of context-dependent experience via embodied action when Carolin demonstrates the size of the clown's shoes as a way of creating sense in the moment. Likewise, when the voice announces that Erik "laughs so much that his stomach hurts," which is associated with an experience of laughing unrestrainedly, or with stomach ache behaviour, a moment of embodied intensity takes place, through mimicking gestures and moving legs.

Read through affect theory, the moments described above highlight the mutually constitutive nature of the e-reading activity in which the voice acts upon the children to act and react, thus affecting each other in shared interdependence and creating movement of mind and body.

\section{Intense mo(ve)ments of repeated reading}

Like the previous example, the following shows what an assemblage involving the reading voice may become, what it can do.

The voice narrates a passage about a tight-rope walker who enters the ring. Carolin scrolls down the text to view the picture of the tight-rope walker, umbrella in one hand for balance. "It looks difficult [Det ser svårt ut]" the voice continues. Oskar pauses the sound recording, declares that the voice has changed while reading before Carolin continues.

C: So, before it was very dark but now he changed it to be a little lighter [Så, innan var den så mörk men nu ändra han till en lite ljusare].

Oskar $(\mathrm{O})$ : Yes. Before it was like very dark, and then it was lighter, and [Ja. Innan var den typ jättemörk, och sen var den ljusare, och]

Carolin asks if they should read the passage again, which they do before continuing to read the narrative. During a pause in the circus show, Erik and his father leave the tent to ride a little pony, but they have to wait because "there was a long line [det var en lång kö]". Carolin pauses the recorded voice to draw a long line with her arm in the air, from left to right, saying, "It's a looong, loooong, long line [Det var en lååång, låååång, lång kö]”. Then both Oskar and Carolin start to repeat what the voice says.

SR: Erik can at last borrow a helmet. [Till slut får Erik låna en hjälm.]

C: Erik

O: Erik

C: Erik can at last borrow a helmet ((showing the rhythm of the voice by moving her hand rhythmically in the air, starting at the level of her tummy and moving slightly diagonally from the body))

SR: Now he sits in the saddle [Nu sitter han i sadeln] 
C: Now he sits in the saddle ((with a rhythmical hand movement as above))

SR: But the interval is over [Men pausen är slut]

$\mathrm{C}$ : But the interval is over ((with a rhythmical hand movement as above))

So they go on repeating what the voice says, over and over again.

It is interesting that the voice also in this example is part of an intensity influencing the reading process of identifying words and simultaneously producing and communicating sense. Unlike the previous example, the words and passages of the text are repeated, both separately and together, over and over again.

A turning point in which this process of repeated reading can be identified occurs when the voice says that walking on a tight-rope "looks difficult", after which Oskar specifically remarks that the pitch of the voice has changed. His statement indicates that something happens as the voice taps into Oskar's body of experiences, something that the children together get involved in, and actually listen to this particular passage again. The combination of the words and the voice pitch change sets things in motion, thus offering new opportunities for the children to associate printed language with spoken language, improving their reading speed and rhythm, and building perceptions of themselves as readers.

This example also illustrates how an assemblage links to "thinking with" the content of the reading. For example, reading "It's a long line" is part of a dynamic interplay between alphabetic text, closeness of bodies, a picture, and the students' experiences. It produces a moment in which Carolin rereads this specific passage somewhat differently than the other passages. She accentuates the word "long" and repeats it several times: "It's a looong, loooong, long line". She also communicates her understanding of the word by drawing a line with her hand in the air, from the far left to the far right of her body.

In specific ways, the analysis maps a simultaneous production of multiple processes associated to reading comprehension in which both the experimentation and the training of intonation, the speed and accuracy of individual words and sentences, as well as the bodily materialization of the words, become significant parts of a process of producing and communicating sense.

\section{Unexpected occurrences organize the e-reading activity}

At the outset of the lesson, the teacher orchestrated the e-reading activity with the ambition of scaffolding metacognitive strategies for better understanding. In the introduction she modeled strategies of summarizing, predicting, making inferences and visualizing. But in the excerpt that follows, Oskar and Carolin intervene in the order of the planned learning-to-read activity, changing and transforming it, making adjustments to the original plan. The efforts of building a reading den interrupt the calculated flow of using metacognitive reading strategies.

Now Oskar twists and turns on the sofa and Carolin tells him to lie still so that he won't fall down, or she will get the teacher. But instead of getting the teacher, she suddenly stands up saying, "Let's make it cosier [Vi gör det lite mysigare]". Immediately they start co-arranging the pillows on the sofa, continually negotiating 


\section{Hermansson}

the emergence of their reading den. They add two blankets on top of the pillows before they crawl in under the blanket with their digital tablet. "How cozy! [Va mysigt!]", Carolin states before starting the sound recording. As Oskar and Carolin lie still, tightly encased in blankets, they turn the sound down. Once again they reread what the voice reads, but now whispering. As the text ends, Carolin asks, "Shall we listen to it once again? [Ska vi lyssna på den en gång till?]”, but they decide not to, as Oskar wants to do something else. They both leave their reading den for the classroom.

Read through affect theory, the intensity of this moment and the sense of shared excitement bring about the building of the reading den and the experience of finishing the e-book. Carolin and Oskar's moments of joy, the intense engagement with the pillows and blankets on the sofa, along with the thought of reading, which may connect with the feeling of mother reading on the sofa at home, invite an exploration of what the reading den can do. As Oskar begins to get jumpy and restless, could the reading den create a sense of peace and quiet and allow a process in which the text is listened to till the end? Sound recording, pillows, bodily closeness, blankets and a sofa are part of this assemblage, cultivating a particular feeling of coziness: the voice is turned down and two bodies under the blankets, tightly side by side, repeat the sentences in a whisper. The elements mix with and expand the capacity to act, producing a new reading process in which a cozy reading den is made and the voice reads the end of the digital narrative. As such, this example draws attention to how shared experiences, social environments and cultural views affect the e-reading activity, just as the ereading activity shapes new experiences, social environments and more. The activity invites alternative experiences of, for example, the force related to the whispering voices of the children, influencing the reading of the narrative to the very end. Thus, processes of reading both shape and are shaped by the e-book activity.

\section{Counting mo(ve)ments of intensity}

The accounts and analyses in this article point to the highly diverse, immediate and indeterminate aspirational strategies that children adopt when reading electronic books. The analysis shows how multiple and diverse moments and movements of e-reading emerge and develop in specific ways through the interaction of bodies, ideas and materiality. Regarding what and how elements become more or less forceful, the analysis shows that the disembodied digital voice is a vital component providing potential for activating engagement in and a drive for reading through the mo(ve)ments of embodied reading when children co-read on their own.

In line with research highlighting how children and e-books are in a "dynamic relationship - one dependent on the other" (Roskos et al., 2014), this article has attended to the importance of both the social practices and the materiality involved in children's engagement in reading. The children's engagement exemplifies individual use of the characteristics of e-books and how they actively participate "when activities are interesting, socially useful or personally enjoyable to them, and within their zone of proximal development" (Roskos, Burstein and You, 2012, p. 48). However, I argue that the analysis suggests that the intense and energetic moments and movements, 
often associated with children's drive for reading, unfold in the encounter between the 'bodies' of the e-book and the children and ideas and the text. Bringing forth the productive power of affect, my discussion of the e-reading activity of "Erik at the Circus" aims to gesture towards the usefulness and need of rethinking the educational literacy tradition that tends to think about our bodies and minds as separate systems. Informed by affect, the analysis provides a language to write and think about children's engagement in e-books and the processes of learning to read without separating body and mind because the focus is on the activity itself and its performative effects, that is, what may 'become'. This is probably the most important consequence for children as it offers a way for teachers to encounter the 'becoming' nature of the e-reader in relation to all the happenings in the classroom (Hermansson, in press) - as immediate and preplanned and indeterminate and ordering happenings in simultaneity.

Riika Hohti (2016) has argued that turning attention to the becomings of openended encounters can play an important role for teachers in addressing "things and actions that mattered to the children" (p. 86). Accordingly, it is here suggested that taking the web of the diverse and multiple happenings in children's daily e-reading activities seriously means attending to a collective child's perspective in which the e-reader is seen as one of many parts in the reading activity (cf. Hermansson, 2011). Despite agreement among scholars on the importance of understanding what is happening in the digital reading classroom, there remains a paucity of studies taking a child's perspective. This study accentuates the need to try to see beyond what we think we know of children and reading in order to attend to what may happen in the digital classroom and to remain sensitive to the productive force of affect. In taking an assembled, collective child's perspective, this study offers insights into how the disembodied voice and children's experiences of embodiment are transformed into mo(ve)ments of repeated reading in a particular rather than universal form. In embodied repeated reading the children engage with interest and enjoyment when living out their feelings and thoughts as e-readers. Significantly, these mo(ve)ments emerge as the children co-read on their own, not through a preplanned and structured model intended to teach reading fluency, with which repeated reading is commonly associated.

In the analysis I have outlined some of the complexity and local significance that lie at the intersection of overlapping forces coming into play. The notion of affect suggests that the intersection of the disembodied voice and the embodied actions in young children's e-reading activities can be used to redefine and speak back to dominant cognitive and metacognitive discourses of reading comprehension. As a site of early childhood pedagogy, engaging with the text of a disembodied voice may mean engaging holistically with the material world through words.

\section{References}

Albrecht-Crane, C. \& Daryl Slack, J. (2003). Toward a pedagogy of affect. In J. Daryl Slack (Ed.), Animations (of Deleuze and Guattari) (pp. 191-216). New York, NY: Peter Lang.

Alvermann, D. (2000). Researching libraries, literacies and lives: A rhizoanalysis. In E. A. St. Pierre \& W. Pillow (Eds.), Working the ruins (pp. 114-129). New York, NY: Routledge 


\section{Hermansson}

Brown, S. (2016). Young learners' transactions with interactive digital texts using e-readers. Fournal of Research in Childhood Education 30(1), 42-56.

Burnett, C. (2009). Research into literacy and technology in primary classrooms: An exploration of understandings generated by recent studies. Fournal of Research in Reading 32(1), 22-37.

Bus, A. G., Takacs, Z. K. \& Kegel, C. A. T. (2014). Affordances and limitations of electronic storybooks for young children's emergent literacy. Developmental Review, 35, 79-97.

Ciampa, K. (2012). Reading in the digital age: using electronic books as a teaching tool for beginning readers. Canadian fournal of Technology, 38(2), 1-26.

Chiong, C., Ree, J., Takeuchi, L. \& Erickson, I. (2012). Comparing parent-child co-reading on print, basic, and enhanced e-book platforms. New York, NY: The Joan Ganz Cooney Center. Available at http://www. joanganzcooneycenter.org/publication/quickreport-print-books-vs-e-books/ 2016-09-21.

Cole, D. R. (2009) Deleuzian Affective Literacy for Teaching Literature: a literacy perspective on multiple literacies theory. In D. Masny \& D. R. Cole (Eds.), Multiple Literacies Theory: a Deleuzian perspective. Rotterdam: Sense.

Colebrook, C. (2002). Understanding Deleuze. Crows Nest, Australia: Allen \& Unwin.

Coleman, B. \& Ringrose, J. (2013). Deleuze and research methodologies. Edinburgh: Edinburgh University Press.

Deleuze, G. (1988). Spinoza: practical philosophy. San Francisco, CA: City Light Books.

Deleuze, G. \& Guattari, F. (1987). A thousand plateaus: Capitalism and schizophrenia. Minneapolis, MN: University of Minnesota Press.

Dufresne, T. (2006). Exploring the processes in becoming biliterate: The roles of resistance to learning and affect. International fournal of Learning, 12(8), 347-354.

Gonzalez, M. (2014). The effect of embedded text-to-speech and vocabulary eBook scaffolds on the comprehension of students with reading disabilities. International fournal of Special Education, 29(3), 111-125.

Goodwin, C. (2000). Action and embodiment within situated human interaction. Fournal of Pragmatics, 32(10), 1489-1522.

Hagood, M. C. (2004). A rhizomatic cartography of adolescents, popular culture, and constructions of self. In K. Leander \& M. Sheehy (Eds.), Spatializing literacy research and practice (pp. 143-160). New York, NY: P. Lang.

Hermansson, C. (in press). Processes of becoming-writer: Thinking with a situated, relational and nomadic analysis to literacy research. Language and Education.

Hermansson, C. (2011). Images of writing and the writing child. Nordisk Barnehageforskning, 4(2), 41-59.

Hickey-Moody, A. \& Malins, P. (2007). Introduction: Gilles Deleuze \& Four Movements in Social Thought. In A. Hickey-Moody \& P. Malins (Eds.), Deleuzian Encounters: Studies in Contemporary Social Issues (pp. 1-24). London: Palgrave Macmillan.

Hohti, R. (2016). Children writing ethnography: Children's perspectives and nomadic thinking in researching school classrooms. Ethnography and Education, 11, 74-90.

Knudsen, B. T. \& Stage, C. (2015). Introduction. Affective Methodologies. In B. T. Knudsen \& C. Stage (Eds.), Affective Methodologies: Developing Cultural Research Strategies for the Study of Affect (pp. 1-22). Hampshire: Palgrave MacMillan.

Leander, K. M. \& Rowe, D. W. (2006). Mapping literacy spaces in motion: A rhizomatic analysis of a classroom literacy performance. Reading Research Quarterly, 41(4), 428-460.

Luke, A., Woods, A. \& Dooley, K. (2011). Comprehension as social and intellectual practice: Rebuilding curriculum in low socioeconomic and cultural minority schools. Theory Into Practice, 50(2), 157-164.

Lysenko, L. V. \& Abrami, P. C. (2014). Promoting reading comprehension with the use of technology. Computers E Education, 75, 162-172.

Mangen, A. (2016). The digitalization of literary reading. Contributions from empirical research. Orbis Litterarum, 71(3), 240-263

Mangen, A. \& Kuiken, D. (2014). Lost in an iPad: Narrative engagement on paper and tablet. Scientific Study of Literature, 4(2), 150-177.

Olsson, L. (2013).Taking children's questions seriously: The need for creative thought. Global Studies of Childhood, 3(3), 230-253.

Rasmusson, M. (2014). Det digitala läsandet: begrepp, processer och resultat [Digital reading - Concepts, Processes, and Results] (Doctoral thesis). Härnösand: Mittuniversitetet.

Roskos, K., Burstein, K. \& You, B. K. (2012). A typology for observing children's engagement with e-Books at preschool. Fournal of Interactive Online Learning, 11, 47-66.

Roskos, K. \& Burstein, K., Shang, Y. \& Gray, E. (2014). Young Children's Engagement With E-Books at School: Does Device Matter? SAGE Open, 4(1), 1-9. 
Schneps, M. H., Thomson, J. M., Chen, C., Sonnert, G. \& Pomplun, M. (2013). E-readers are more effective than paper for some with dyslexia. Plos One, 8(9), 1-9.

Seyfert, R. (2012). Beyond Personal Feelings and Collective Emotions: Toward a Theory of Social Affect. Theory, Culture E Society 29(6) 27-46.

Smeets, D. J. H. \& Bus, A. G. (2012). Interactive electronic storybooks for kindergartners to promote vocabulary growth. Fournal of Experimental Child Psychology, 112, 36-55.

Statistics Sweden (2014). Statistiska Centralbyrån [Statistics Sweden]. Available at http://www.scb.se/ 2016-03-10.

Swedish National Agency for Education (2001). Att bygga en ny skolform för 6-åringarna: Om integrationen förskoleklass, grundskola och fritidshem [Building a new type of school for six-year olds: On the integration of preschool class, primary school and after-school centre]. Stockholm: The Swedish National Agency for Education.

Swedish National Agency for Education (2011) Curriculum for the compulsory school, preschool class and the leisure-time centre 2011. Stockholm: The Swedish National Agency for Education.

Swedish National Agency for Education (2012). PIRLS 2011, läsförmågan hos svenska elever $i$ årskurs4 $i$ ett internationell perspektiv [PIRLS 2011, the reading literacy of Swedish year 4 pupils in an international perspective]. Available at http://www.skolverket.se/publikationer?id=2941 2016-05-21.

Takacs, Z. K., Swart, E. K. \& Bus, A. G. (2015). Benefits and pitfalls of multimedia and interactive features in technology-enhanced storybooks: A meta-analysis. Review of Educational Research 85(4), 698-739.

Verhallen, M. J. A. \& Bus, A. G. (2011). Young second language learners' visual attention to illustrations in storybooks. Fournal of Early Childhood Literacy, 11(4), 480-500.

Westlund, B. (2013). Att bedöma elevers läsförståelse: en jämförelse mellan svenska och kanadensiska bedömningsdiskurser $i$ grundskolans mellanår [To assess reading comprehension: a comparison between Swedish and Canadian assessment discourses in upper elementary school] (Doctoral thesis). Stockholm: Stockholms universitet. 